\title{
A NEW ANNOTATED LIST OF MANITOBA FERNS (SPRING, 2016)
}

Richard J. Staniforth

336 Glenwood Crescent

Winnipeg, MB R2L 1J9

richard_staniforth@yahoo.ca

Most people who have interests in nature have enjoyed the pleasure of seeing ferns in their natural habitats; whether they have been large graceful stands of Ostrich ferns growing in spring-flooded, riverine forests; stately patches of bracken in among fragrant pines; or even the various kinds of rock ferns thriving in the smallest of crevices in granite or limestone outcroppings. Ferns bring a tranquil pleasure to their spectators, which is different to that provided by the bright colours that attract us to many flowering plants. In this article, I hope to update our understanding of ferns in Manitoba with the use of the reliable evidence that herbarium specimens can provide. During the early months of 2016, I examined the fern collections of herbaria at University of Winnipeg (UWPG), University of Manitoba (WIN), The Manitoba Museum (MMMN) and my own temporary collection (RS) but occasionally the research led to herbaria and information sources from elsewhere.

Hopefully, the resulting annotated checklist will be a baseline datum for future studies and will also update the most recent list of Manitoba's plant biota. ${ }^{1}$ Horsetails and moonworts are also ferns in the truest meaning of the term, but these have not been included here because they have already been fully reported in previous articles in the Blue Jay. ${ }^{2,3}$ This article is restricted to the "true" or leptosporangiate ferns. Altogether 1,421 specimens of ferns were examined, their identifications were verified and notes taken regarding their ranges and habitats. There are several common names for most kinds of ferns, even within the same region. The ones chosen for the checklist are those that are most commonly used, or seem to be the most logical names for those species. Alternative names that have occasionally been selected in important publications involving ferns are given below for clarification. ${ }^{4,5}$

\section{Eastern Lady-fern}

Ladyfern $^{4}$ (Fig. 1)

Athyrium filix-femina (Linnaeus) Roth ex Mertens var. angustum (Willdenow) G. Lawson

Very common. HABITAT: Wet organic soils in deciduous and mixed woodlands, bogs, fens, stream banks and roadside ditches.

RANGE: Southern half of Manitoba, but less commonly west of Red River. A few northern specimens show a minority of characteristics of the Northern Lady-fern, A. filix-femina var. cyclosorum Ruprecht.

\section{American Parsley-fern}

American Rockbrake ${ }^{4}$,

American Rock-fern ${ }^{5}$

Cryptogramma acrostichoides R. Brown Uncommon. HABITAT: Depressions and crevices on granite outcrops. RANGE: From SE to mid-western Manitoba.

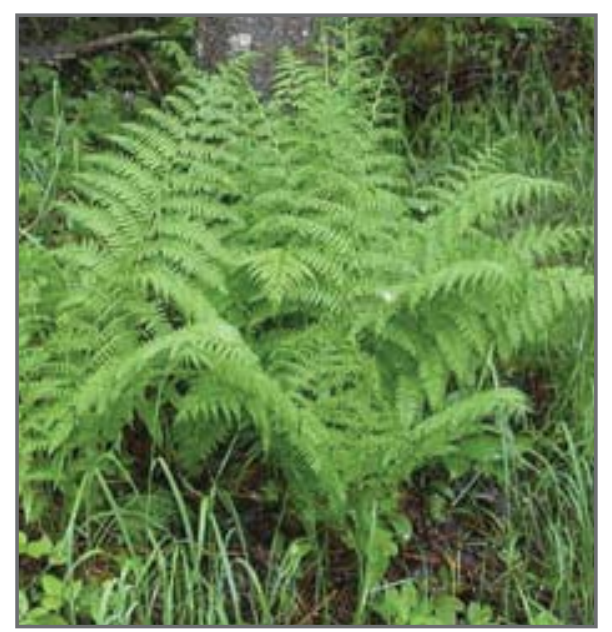

\section{Bulblet Bladder-fern}

Bulblet Fern ${ }^{4}$ (Fig. 2)

Cystopteris bulbifera (Linnaeus)

Bernhardi

Very rare. A single specimen (MMMN 39) was collected from "Eastern Manitoba" by M.W. Hutchison in 1944. No additional information is given on the herbarium label.

\section{Brittle Bladder-fern}

Fragile Fern ${ }^{4}$, Fragile Bladder-fern ${ }^{5}$ Cystopteris fragilis (Linnaeus) Bernhardi

\section{Common. HABITAT: Moist organic} substrates in shaded crevices and mossy ledges on calcareous cliffs in mixed or coniferous forests.

Occasionally found on granite and other rock types, rarely on rotten logs within forests. RANGE: It is found from SE and across the southern half of the province north to Lynn Lake, but also at Churchill where it appears to be disjunct.

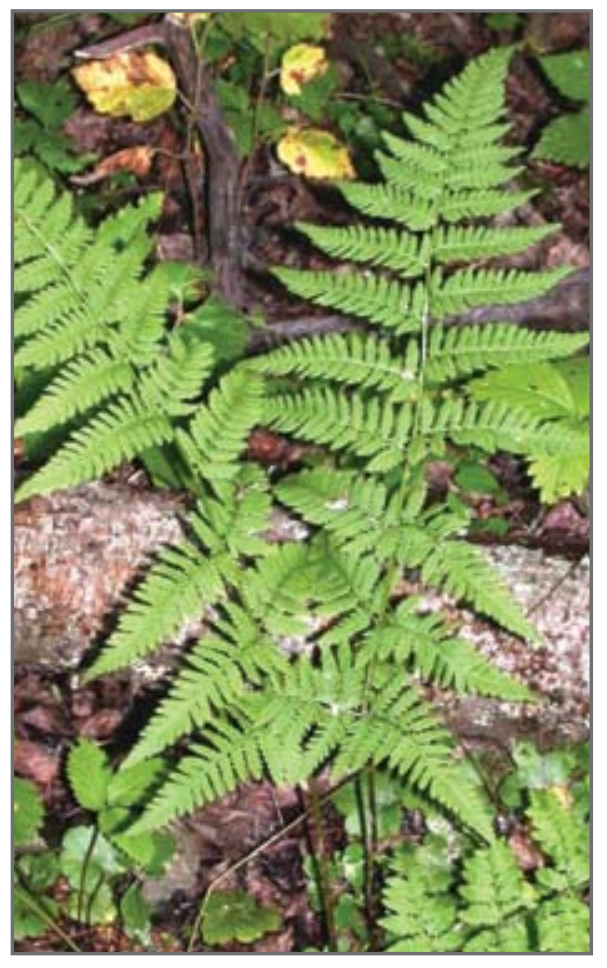

FIGURE 1. Manitoba's commonest ferns; Eastern Lady-fern (left); Spinulose Wood-fern (right); 


\section{Mackay's Bladder-fern}

Upland Brittlefern ${ }^{4}$ (Fig. 2)

Cystopteris tenuis (Michaux) Desvaux

Rare. HABITAT: Shady calcareous and granite cliffs in the boreal forest. RANGE: Similar to the Fragile Bladderfern but scarcer and more southern and eastern. Formerly known as $C$. fragilis var. mackayi Lawson but was elevated to species status in $1983 .{ }^{6}$ This is the first report of this taxon from Manitoba; however, specimens at the Manitoba Museum had been casually annotated as "var. tenuis" by D. Brunton in 1986.

\section{Spinulose Wood-fern} Spinulose Shield-fern ${ }^{4,5}$ (Fig. 1) Dryopteris carthusiana (Villars) H.P. Fuchs

Very common. HABITAT: Moist organic soil, and occasionally on rocks, in deciduous, mixed and coniferous forests. RANGE: Throughout the southern half of Manitoba.

\section{Crested Wood-fern}

Crested Shield-fern ${ }^{4,5}$

Dryopteris cristata (Linnaeus) A. Gray

Common. HABITAT: Wet organic substrates in bogs, fens and wet scrub and woodlands. RANGE: Southern one-third of Manitoba.

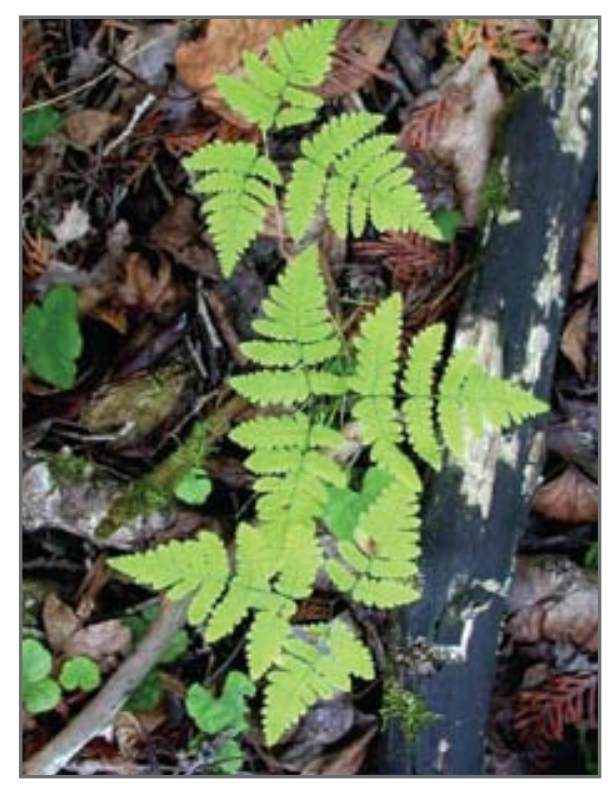

FIGURE 1. Common Oak-fern (left); Ostrich fern (right). 7a. Braun's Hybrid Wood-fern

Dryopteris x uliginosa (A. Braun ex Döll) Kuntze ex Druce = Dryopteris carthusiana x D. cristata

Very rare. HABITAT: Mixed and coniferous forests in the vicinity of both parent species; specimens are sterile and show characteristics of each. This is the first report of this hybrid for Manitoba.

\section{Northern Wood-fern}

Spreading Woodfern ${ }^{4}$ (Fig. 2) Dryopteris expansa (C. Presl) FraserJenkins \& Jermy

Very rare. A single specimen was collected from a streamside granite outcrop in the Gunisao Lake area $\left(53^{\circ} 29^{\prime} \mathrm{N} ; 96^{\circ} 18^{\prime} \mathrm{W}\right)$ of mid-eastern Manitoba. This is the first report of this taxon from Manitoba. Although this specimen has all of the characteristic features of the Northern Wood-fern, it has been pointed out that its petiolar bracts do not exhibit the strongly marked central midrib usually found in this species (D. Brunton, pers. comm.).

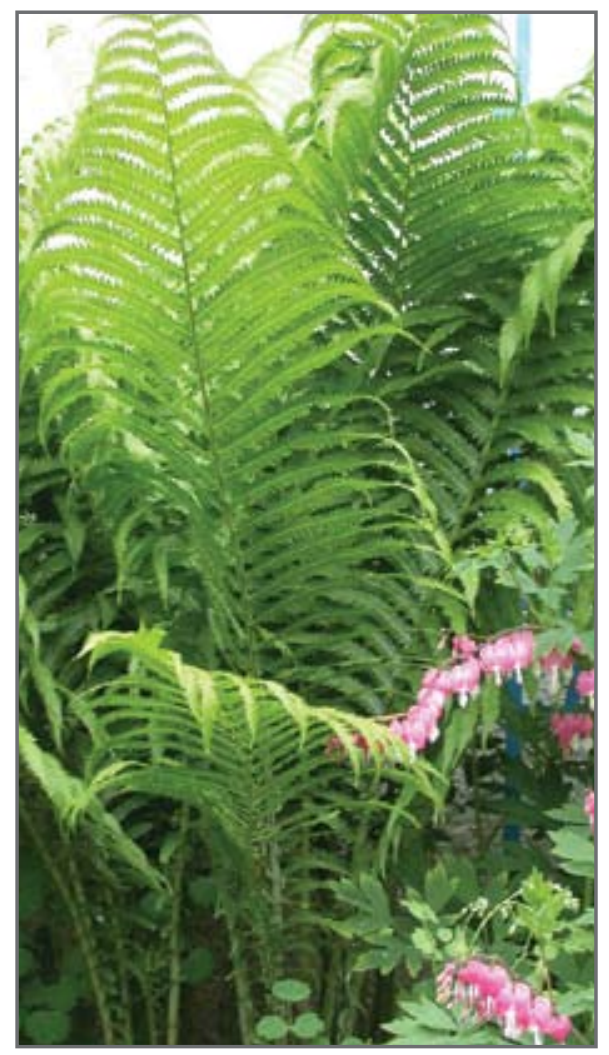

\section{Fragrant Wood-fern}

Fragrant fern ${ }^{4}$, Fragrant Shield-fern ${ }^{5}$ Dryopteris fragrans (Linnaeus) Schott

Uncommon. HABITAT: Shady, noncalcareous cliffs on outcrops in the south but on exposed rock ridges northwards. RANGE: SE Manitoba and northwards to the Nunavut border.

\section{Common Oak-fern}

Northern Oak Fern ${ }^{4}$ (Fig. 1)

Gymnocarpium dryopteris

(Linnaeus) Newman

Very common. HABITAT: On moist, organic soils in mixed and coniferous woodlands or amongst rocks. RANGE: From the Whiteshell Provincial Park in SE MB across Manitoba to Riding Mountain National Park and northwards to the Nunavut border.

\section{Nahanni Oak-fern}

Gymnocarpium jessoense (Koidzumi)

Koidzumi subsp. parvulum Sarvela

Rare. HABITAT: Usually on ledges on limestone or granite outcrops in mixed or coniferous forests.

RANGE: Similar to that of Common Oak-fern but much scarcer.

\section{1a. Intermediate Oak-fern}

Gymnocarpium x intermedium

Sarvela = Gymnocarpium

jessoense x G. dryopteris

Very rare, but likely commoner than records indicated. Found in proximity to parent species, i.e. rocky boreal woodlands.

\section{Limestone Oak-fern}

Gymnocarpium robertianum

(Hoffmann) Newman

Very rare. HABITAT: Shady limestone cliffs and rocks, also cedar swamps. RANGE: Collected from four locations in Manitoba: north of Cranberry, 37 $\mathrm{km}$ and $50 \mathrm{~km} \mathrm{~N}$ of Grand Rapids and near the North Star Trail, E of Grand Beach Provincial Park. K. Pryer has thoroughly reviewed the occurrence of oak-ferns in Manitoba. ${ }^{7}$ 


\section{Hairy Water Clover}

Hairy Water Fern ${ }^{4}$, Hairy Pepperwort ${ }^{5}$, Water Shamrock (Fig. 2)

Marsilea vestita Hooker \& Greville

Very rare. A single specimen (WIN 6250 ) is the only evidence of its occurrence in Manitoba. It may be more frequent but overlooked because it is inconspicuous. It occurs in adjacent parts of Saskatchewan, although not commonly ${ }^{5}$. The herbarium label on the Manitoba specimen indicated that it was collected from "Western Manitoba", but gives no additional information.

\section{Ostrich Fern (Fig. 1)}

Matteuccia struthiopteris (Linnaeus) Todaro var. pensy/vanica (Willdenow) C.V. Morton

Very common. HABITAT: Wet or seasonally flooded deciduous or mixed woodlands, frequent in river bottomland forests. RANGE: The southern half of Manitoba. A popular garden plant with edible fiddleheads. ${ }^{8}$

\section{Sensitive Fern}

\section{Onoclea sensibilis Linnaeus}

Common. HABITAT: Wet, shrubby, mixed or deciduous forests, swamps and roadside ditches.

RANGE: SE Manitoba. Beaver Creek Provincial Park ( $51^{\circ} 22^{\prime} \mathrm{N}$; $96^{\circ} 55^{\prime} \mathrm{W}$ ) is the most northerly and westerly outpost for the entire range of this primarily eastern species.

\section{Interrupted Fern}

Osmunda claytoniana Linnaeus

Uncommon. HABITAT: Damp locations in deciduous, mixed or coniferous forests. RANGE: SE Manitoba. A specimen collected from near Hamar's Lake within Hecla Provincial Park $\left(51^{\circ}\right.$ $11^{\prime} \mathrm{N} ; 96^{\circ} 55^{\prime} \mathrm{W}$ ) is the most western location for this primarily eastern species.

\section{Gastony's Cliff-brake}

Pellaea gastonyi Windham

Very rare. HABITAT: Dolomite and limestone outcrops and boulders. RANGE: A few colonies are known from the central and northern Interlake region of Manitoba. These were thoroughly documented by $C$. Friesen and C. Murray in 2015.9

\section{Smooth Cliff-brake}

Pellaea glabella Mettenius ex Kuhn ssp. glabella

Very rare. Known from only one location in Manitoba $\left(49^{\circ} 44^{\prime} \mathrm{N}\right.$; $95^{\circ}$ $\left.10^{\prime} \mathrm{W}\right)$; on the Hunt Lake Hiking Trail in Whiteshell Provincial Park where it has been found growing in moist crevices on a single, shaded, vertical, northfacing cliff of metamorphic rock within the boreal mixed forest.

\section{8a. Western Smooth Cliff-brake}

Western Dwarf Cliffbrake ${ }^{4}$

Pellaea glabella Mettenius ex Kuhn ssp. occidentalis (E. Nelson) Windham Rare. HABITAT: Exposed and partially shaded sites on limestone and dolomite cliffs within the southern edge of the boreal forest.

RANGE: Mid-western Manitoba.

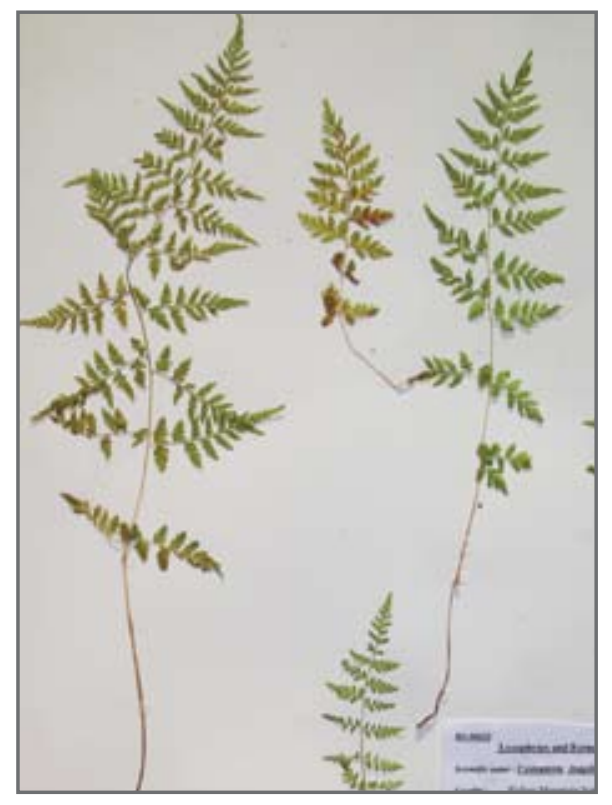

FIGURE 2. From left to right: Two new ferns for Manitoba; Mackay's Bladder-fern; Northern Wood-fern.

\section{Northern Beech-fern}

Phegopteris connectilis (Michaux) Watt

Very rare. This species has only been collected twice in Manitoba: Kasmere Lake, NW Manitoba (approx. 59 $35^{\prime} \mathrm{N} ; 101^{\circ} 10^{\prime} \mathrm{W}$ ) and, secondly, Tod Lake, W-central Manitoba (approx.56 $34^{\prime} \mathrm{N}$; $101^{\circ} 46^{\prime} \mathrm{W}$ ).

\section{Siberian Polypody}

Polypodium sibiricum Siplivinsky

Uncommon. HABITAT: Crevices and depressions on moist, mosscovered, shaded granite (occasionally calcareous) outcroppings.

RANGE: SE to NW Manitoba.

\section{Common Rock Polypody}

Rock Polypody ${ }^{4}$

Polypodium virginianum Linnaeus

Common. HABITAT: Crevices and depressions on moist, moss-covered, shaded granite (occasionally calcareous) outcroppings.

RANGE: SE to NW Manitoba. The Common Rock Polypody is the commoner of the two Polypody species in the southeast the province; however the Manitoba ranges of the two species overlap.

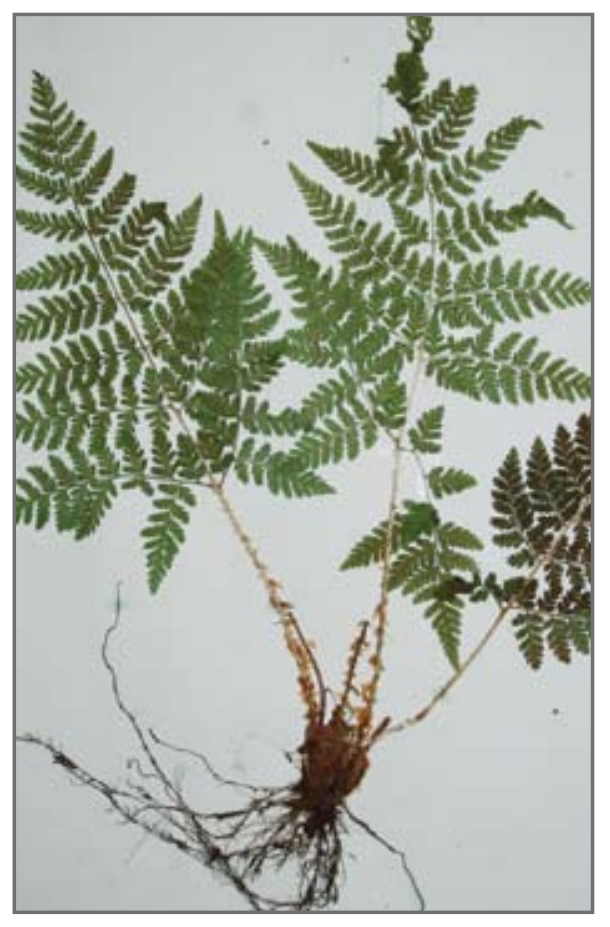




\section{Eastern Bracken}

Bracken Fern ${ }^{4}$

Pteridium aquilinum (Linnaeus) Kuhn var. latiusculum (Desvaux) Underwood ex A. Heller

Common. HABITAT: Well-drained and dry soils in mixed and coniferous forests, or adjacent roadsides. RANGE: SE Manitoba with disjunct colonies in Riding Mountain National Park ${ }^{10}$ and Kettle Hills.

\section{Marsh Fern}

\section{Eastern Marsh Fern ${ }^{4}$}

Thelypteris palustris Schott var. pubescens (Lawson) Fernald

Uncommon. HABITAT: Fens, bogs, roadside ditches and open, wet, grassy areas in boreal woodlands.RANGE: SE Manitoba with a disjunct population near Grand Rapids (53 $20^{\prime} \mathrm{N}$; $98^{\circ} 20^{\prime}$ W).

\section{Alpine Woodsia}

Northern Woodsia ${ }^{4}$

Woodsia alpina (Bolton) S.F.Gray

Very rare. HABITAT: moist, shaded, granite or metamorphic outcroppings within the boreal forest ${ }^{11,12}$.

RANGE: Collected from four sites in Manitoba: Tod Lake, Snow Lake, Lake Waskaiowaka and Hunt Lake in the Whiteshell Provincial Park. W. Cody and $D$. Britton have reviewed the status of Woodsia in Manitoba. ${ }^{11,12}$
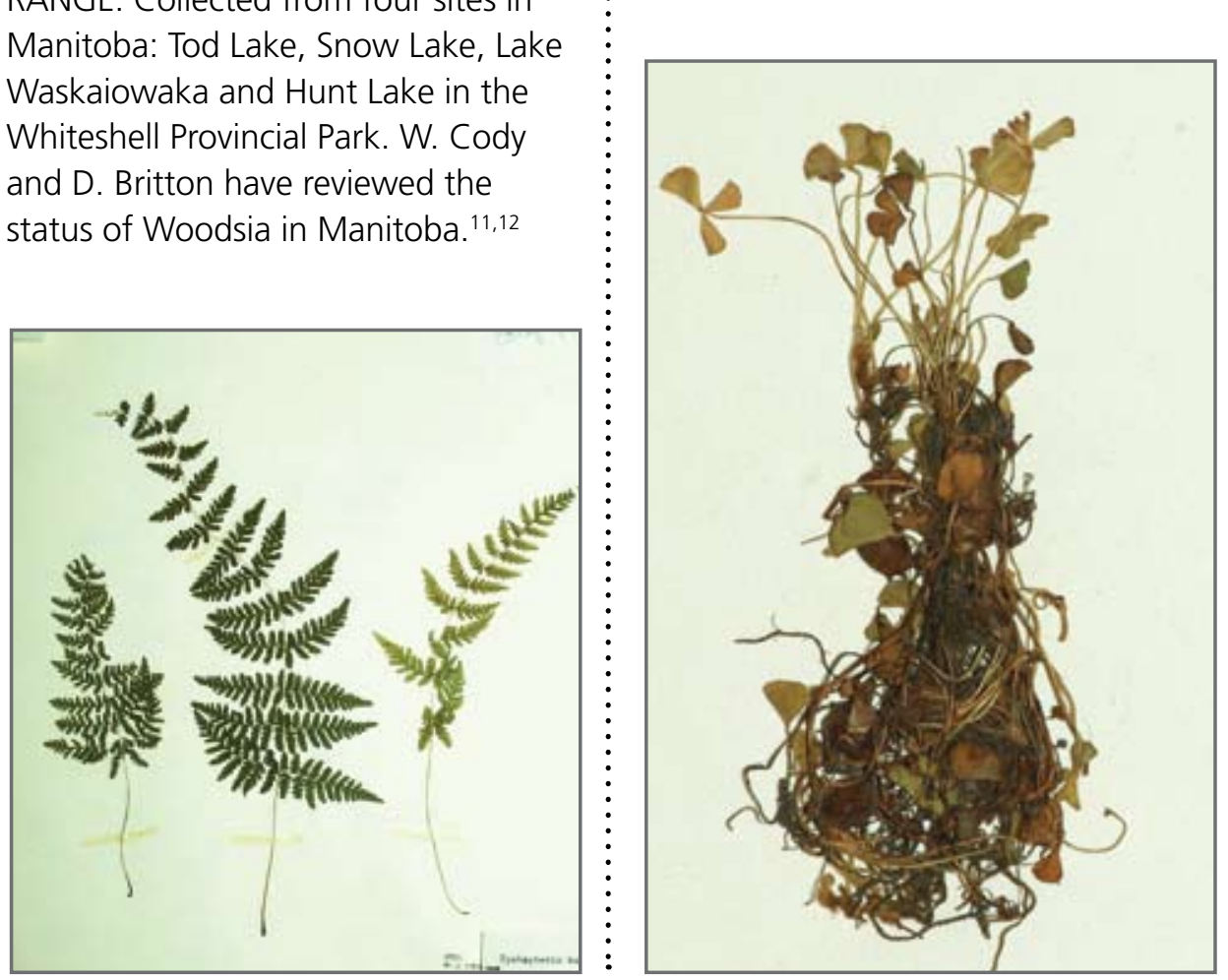

FIGURE 2. Two old, unique and mysterious Manitoba fern specimens; Bulblet Bladder-fern, Hairy water-clover

\section{Smooth Woodsia}

Woodsia glabella R. Brown ex

Richardson

Rare. HABITAT: Shaded crevices in limestone and dolomite cliffs.

RANGE: Northern Interlake region, westward to the Saskatchewan border.

\section{Rusty Woodsia}

Woodsia ilvensis (Linnaeus) R. Brown

Very common. HABITAT: Exposed crevices and depressions on PreCambrian granite outcroppings in the boreal forests. RANGE: From Whiteshell Prov. Park in SE Manitoba to the Nunavut border. ${ }^{12}$

\section{Oregon Woodsia}

Woodsia oregana D.C. Eaton ssp. oregana

Very rare. Collected from two locations in Manitoba; on a schist rock outcrop in Baker's Narrows Provincial Park $\left(54^{\circ} 40^{\prime} \mathrm{N} ; 101^{\circ} 39^{\prime} \mathrm{W}\right)$, and secondly just a few kilometres closer to Flin Flon. Manitoba specimens had been previously mistakenly identified as the pubescent subspecies cathcartiana (B.L. Robinson) Windham.

\section{7a. Hybrid Woodsia}

Woodsia $\times$ abbeae Butters $=W$. oregana $\times$ W. ilvensis

Specimens have been collected from among a colony of Oregon Woodsia near Baker's Narrows Provincial Park and are the mistaken basis of a record of $W$. scopulina for Manitoba. This is the first report of this taxon for Manitoba.

\section{Synopsis of fern taxa in Manitoba}

In Manitoba, there are 27 species, one additional subspecies and three hybrids. Perhaps not surprisingly, the diversity of ferns that occur in Manitoba is not very different to that of Saskatchewan ${ }^{5}$. However, the fern flora of Saskatchewan includes several species that have ranges that do not extend eastwards as far as Manitoba: Rocky Mountain Woodsia, Sitka Lady-fern, Mountain Bladderfern and the Male Fern. Similarly, Manitoba has several species that are primarily eastern and do not reach as far west as Saskatchewan: Interrupted Fern, Sensitive Fern, Northern Woodfern, Mackay's Bladder-fern, Bulblet Bladder-fern, Eastern Bracken, Limestone Oak-fern and Smooth Cliffbrake. Needless to say, both provinces harbour species of ferns that reach their north-eastern or north-western North American range limits.

\section{The commonest of Manitoba Ferns (Fig. 1)}

The sequence of species for which the most specimens had been collected was: Spinulose Wood-fern, Eastern Lady-fern, Common Oak-fern, Ostrich Fern and Rusty Woodsia. These are all common species; however, it must be borne in mind that collection biases may enter this and into the next calculation. 


\section{The rarest of Manitoba Ferns}

Eight Manitoba species of ferns were particularly noteworthy for their scarcity in herbarium collections. Hairy Water-clover, Northern Woodfern and Bulblet Bladder-fern were represented by single specimens. Other rare ferns are Oregon Woodsia and Smooth Cliff-brake each of which had been found from single locations; Baker's Narrows Provincial Park and on the Hunt Lake Trail, Whiteshell Provincial Park, respectively. Other very rare or much localised fern species are Northern Beech-fern, Gastony's Cliff-brake, Limestone Oak-fern and Alpine Woodsia. The last species was found close to the site which bears the single small colony of Smooth Cliffbrake and probably should receive protection.

\section{Two intriguing fern mysteries (Fig. 2)}

Bulblet Bladder-fern and the Hairy Water-clover are each represented in Manitoba's flora by single specimens that were collected a long time ago and have not been seen in the province since. Incomplete information on the herbarium labels has added to their mystery and intrigue.

The Bulblet Bladder-fern is a species of the eastern United States as far north and west as Minnesota and northern Ontario. A specimen was collected by M.W. Hutchison on July 22, 1944 from "Eastern Manitoba" and is now in the Herbarium of the Manitoba Museum (MMMN 39). Its identification has been verified by Scoggan (1950), Boivin (1964) and Cody (1984). Whereas, there has been no doubt about its identification, its

\section{ARGENTINA WILDLIFE FROM PATAGONIA TO MARSHES November 9 - 22, 2016}

Worldwide Ecotours Worldwide Ecotours is offering an exciting up-close encounter with the wildlife of Patagonia and Ibera Marshes. Tango with penguins, Capybara, Rhea, and other South American wildlife.Your tour host, Leslie Tuchek, is an ecological educator who has guided tours for the University of Saskatchewan

Distance Education for eight years. Leslie is an avid birder, nature lover and wildlife photographer.

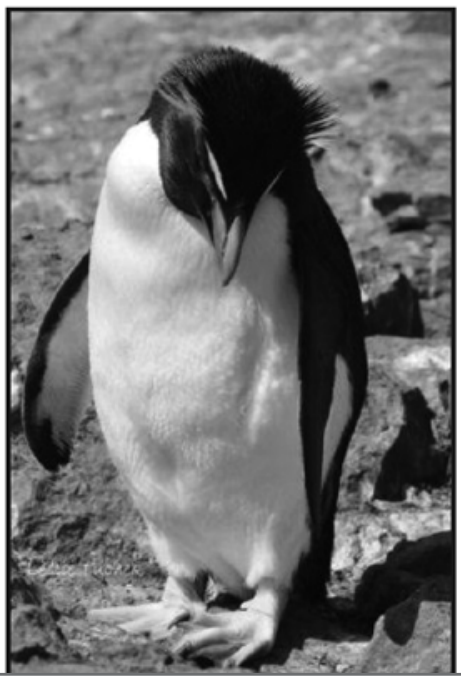

\section{For more information \&} detailed itinerary contact:

\section{Leslie Tuchek}

leslie.tuchek@usask.ca

Tel: 306.230.094I

\section{Ruth MacRae}

ruth@worldwideecotours.com

Tel: I-888-778-2378

origin has remained a mystery. Boivin has speculated that this specimen had been collected from elsewhere in its range with the purpose of a providing a sample to represent a species whose distribution was once mistakenly considered to include "Eastern Manitoba." On the other hand, a recent publication of ferns by Chadde does indicate that the species is widespread in northern Minnesota including Roseau County which is adjacent to the Manitoba border. ${ }^{13}$ Scoggan has succinctly summarised the present status of Bulblet Bladderfern in Manitoba with his statement: "Further collections of this species are desirable to remove all doubt as to its occurrence in the province." 14

The Hairy Water-clover is a strange fern that inhabits shallow water or water-edge muck. Its two kinds of leaves are "un-fernlike" in shape. The aerial or floating ones resemble the leaves of a four-leaved clover and the submerged leaves are fertile and resemble small nutlets. This strange fern is an uncommon species in the American Midwest and the three western Canadian provinces. In Saskatchewan, it is widely but uncommonly distributed across the southern part of the province ${ }^{5}$. There is a specimen in the herbarium of the University of Manitoba that is labelled "Western Manitoba" (WIN 6250) but the exact location and date of collection, and the collector's name are not provided on the herbarium label. With reference to the occurrence of Hairy water-clover in Manitoba, Cody has made the statement: "The species should be searched for in Western Manitoba". ${ }^{12}$

\section{Special fern places}

Manitoba fern specimens had been collected from a variety of ecosystems: moist woodlands, marshes, roadsides, limestone escarpments and granite outcroppings. There were more species in the southeast quadrant of the province and the least numbers 
in the northwest quadrant. This is unlikely to be a phenomenon that is entirely related to collection bias because those ecosystems with few species outside of the southeast corner were those which were prone to forest fires, dry sandy substrates in pine forests or in areas of intense agriculture. Limestone escarpments harbour interesting fern species such as the Smooth and Gastony's Cliffbrakes, Smooth Woodsia and the Limestone Oak-fern, and yet these habitats are vulnerable to quarrying which may put their inhabitants at risk. Two specific non-limestone sites are also particularly noteworthy, firstly Baker's Lake Provincial Park in which Manitoba's only colony of Oregon Woodsia is to be found, and secondly the Hunt Lake Trail in the Whiteshell Provincial Park where cliffs support the only Manitoba colony of the Smooth Cliff-brake (Pellaea glabella glabella), as well as a few plants of the rare Alpine Woodsia.

I am very grateful to Diana Bizecki Robson and Janis Klapecki at the Manitoba Museum, to German Avila-Sakar at the University of Winnipeg and to Bruce Ford at the University of Manitoba for allowing me to study their Manitoba fern collections. Also, Jessica Elliott and Jason Kelly of Parks Branch, Manitoba Conservation who facilitated collection permits for provincial parks. Thanks go to Chris Friesen and staff at the Manitoba Conservation Data Centre for information on rare fern sites and to Dan Brunton for stimulating and interesting discussions about many issues concerning ferns. I am most grateful to both the anonymous reviewer and to editor Annie McLeod for their encouragement and excellent advice.
1. Punter, E. (1995) Manitoba's Vascular Plants. Manitoba Conservation Data Centre, Winnipeg, MB.

2. Staniforth, R.J. (2013). Horsetails and scouring-rushes (Equisetum spp.) in Manitoba. Blue Jay 71(1) 48-67.

3. Staniforth, R.J. (2011) Ophioglossid ferns in Manitoba: moonworts, grapeferns and northern adder's-tongue. Blue Jay 69(2) 75-87.

4. The Flora of North America Association (1993) Flora of North America. Vol 2: Pteridophytes and Gymnosperms. Oxford University Press, Inc. New York, NY.

5. Harms, V.L. and Leighton, A.L. (2011). Ferns and fern allies of Saskatchewan. Flora of Saskatchewan Fascicle 1. Nature Saskatchewan Special Publication \#30. Publ. by Flora of Saskatchewan Association and Nature Saskatchewan, Regina, SK.

6. Moran, R.C. (1983) Cystopteris tenuis (Michx.) Desv.: A poorly understood species. Castanea 48: 218-223.

7. Pryer, K. M. (1990) The limestone oak fern: New to Manitoba. Blue Jay 48(4): 192-195.

8. Greenwood, D. R. (2015) Ferns for Canadian gardens, with fronds like these who needs anemones? The Gardener 21(3) 20-26.

9. Friesen, C. and Murray, C. (2015). Gastony's Cliffbrake (Pellaea gastonyi) in Manitoba: new records and assessment of conservation status. Canadian FieldNaturalist 129(1): 45-52.

10. Cody, W.J. (1988) Plants of Riding Mountain National Park. Publication 1818/E, Research Branch, Agriculture Canada, Ottawa, ON.

11. Cody, W.J. and Lafontaine, J.D. (1975) The fern genus Woodsia in Manitoba. The Canadian Field-Naturalist 89: 66-69.

12. Cody, W.J. and Britton, D.M. (1989) The ferns and fern allies of Canada. Ottawa, ON.

13. Chadde, S.W. (2013) Midwest Ferns. A field guide to the ferns and fern relatives of the north central United States. Self-published by S.W. Chadde. Printed by CreateSpace Independent Printing Platform. USA.

14. Scoggan, H.J. (1957) The flora of Manitoba. National Museum of Canada. Bulletin No. 140. Biological Sciences No. 47. Department of Northern Affairs and National Resources, Ottawa, ON.

\section{CALL FOR REGIONAL COORDINATORS SASKATCHEWAN BREEDING BIRD ATLAS}

Bird Studies Canada is currently seeking volunteers to serve as Regional Coordinators (RCs) to help manage coverage of the Saskatchewan Breeding Bird Atlas. The Atlas is scheduled to run from 2017 to 2021 and aims to document the distribution and abundance of breeding birds across the province. Regional Coordinators play a vital role in the success of an Atlas: they act as the main contact and information source for participants within their region; and they work with Atlas staff to ensure that regional coverage targets and data quality standards are met. People interested in serving as RCs should have solid bird identification skills and knowledge of the breeding birds likely to be found in their region. Regions for the southern half of the province are currently based on birding districts; however, these will be modified based on the locations of our RCs and from input at our Fall 2016 Regional Coordinator meeting. We will be hosting the Regional Coordinator meeting at a scenic location over the weekend of October 29-30, 2016. It will be a great opportunity to learn more about the project, meet the Atlas staff and your fellow RCs, and to enjoy some fall birdwatching. If you are interested in making this significant contribution to the Saskatchewan Breeding Bird Atlas by serving as a Regional Coordinator and would like more information, please contact Bird Studies Canada at skatlas@birdscanada.org or call us at 306-249-2894. 